\title{
Increased NTPDase Activity in Lymphocytes during Experimental Sepsis
}

\section{Claudia de Mello Bertoncheli, ${ }^{1}$ Carine Eloise Prestes Zimmermann, ${ }^{2}$ Jeandre Augusto dos Santos Jaques, ${ }^{2,3}$ Cláudio Alberto Martins Leal, ${ }^{3}$ Jader Betsch Ruchel, ${ }^{2,3}$ Bruna Cipolatto Rocha, ${ }^{2}$ Kelly de Vargas Pinheiro, ${ }^{2}$ Viviane do Carmo Gonçalves Souza, ${ }^{2}$ Daniel Roulim Stainki, ${ }^{2}$ Sônia Cristina Almeida Luz, ${ }^{1}$ Maria Rosa Chitolina Schetinger, ${ }^{3}$ and Daniela Bitencourt Rosa Leal ${ }^{2}$}

${ }^{1}$ Centro de Ciências da Saúde, Departamento de Microbiologia e Parasitologia, Universidade Federal de Santa Maria, 97105-900 Santa Maria, RS, Brazil

${ }^{2}$ Centro de Ciências da Saúde, Departamento de Patologia, Universidade Federal de Santa Maria, 97105-900 Santa Maria, RS, Brazil

${ }^{3}$ Centro de Ciências Naturais e Exatas, Departamento de Química, Universidade Federal de Santa Maria, 97105-900 Santa Maria, RS, Brazil

Correspondence should be addressed to Daniela Bitencourt Rosa Leal, dbitencourtrosaleal@gmail.com

Received 24 October 2011; Accepted 19 December 2011

Academic Editor: Angelo A. Manfredi

Copyright (C) 2012 Claudia de Mello Bertoncheli et al. This is an open access article distributed under the Creative Commons Attribution License, which permits unrestricted use, distribution, and reproduction in any medium, provided the original work is properly cited.

We investigated in rats induced to sepsis the activity of ectonucleoside triphosphate diphosphohydrolase (NTPDase; CD39; E.C. 3.6.1.5), an enzyme involved in the modulation of immune responses. After 12 hours of surgery, lymphocytes were isolated from blood and NTPDase activity was determined. It was also performed the histology of kidney, liver, and lung. The results demonstrated an increase in the hydrolysis of adenosine- $5^{\prime}$-triphosphate (ATP) $(P<0.01)$, but no changes regarding adenosine$5^{\prime}$-monophosphate (ADP) hydrolysis $(P>0.05)$. Histological analysis showed several morphological changes in the septic group, such as vascular congestion, necrosis, and infiltration of mononuclear cells. It is known that the intracellular milieu contains much more ATP nucleotides than the extracellular. In this context, the increased ATPasic activity was probably induced as a dynamic response to clean up the elevated ATP levels resulting from cellular death.

\section{Introduction}

Sepsis is characterized by an inflammatory reaction as a consequence of immune system response to bacterial infection $[1,2]$. The immune system has an important role in the pathogenesis of sepsis, which may cause tissue damage and lead to organic failure $[3,4]$. The main process involves the activation of inflammatory cells such as leukocytes, tissue macrophages, dendritic cells, and eosinophils [5]. The exacerbated activation of innate immune response is one of the main components involved in the physiopathology of sepsis, which can be identified by increased proinflammatory factors after infection [6].
The membrane bound enzyme ectonucleoside triphosphate diphosphohydrolase (NTPDase; CD39; E.C. 3.6.1.5) modulates adenine nucleotides level, which are fundamental to the modulation of immune responses [7]. The enzymes of this family are widely distributed in animal tissues and represent the main ectoenzyme expressed by endothelial cells and muscle cells of the circulatory system [8,9]. Under physiological conditions, the nucleotides are present in the extracellular environment in low concentrations, usually nanomolar, but may be found up to micromolar levels [10]. It is known that extracellular ATP, for example, when in micromolar concentrations, can induce the formation of pores in the cell membranes, resulting in osmotic changes [11], and it can also induce two antagonistic effects: cell 
proliferation, when in low concentrations, and cell death, when in high concentrations [10].

Considering the involvement of adenine nucleotides hydrolysis in the modulation of immune system and the participation of immune response in sepsis, the purpose of this study was to evaluate the hydrolysis of ATP and ADP in lymphocytes from rats with induced sepsis.

\section{Materials and Methods}

2.1. Chemicals. Adenosine $5^{\prime}$-triphosphate disodium salt (ATP), adenosine $5^{\prime}$-diphosphate sodium salt (ADP), bovine serum albumine, Trizma base, Trypan Blue solution, and Coomassie Brilliant Blue G were obtained from SigmaAldrich (St. Louis, MO, USA). Ficoll-Hypaque (Lymphoprep) was purchased from Nycomed Pharma (Oslo, Norway). Physiological solution $(0.9 \mathrm{~g} \mathrm{NaCl} / 100 \mathrm{~mL}$ distilled water) was obtained from Fresenius KABI (Brazil). $\mathrm{K}_{2} \mathrm{HPO}_{4}$ was purchased from Reagen (Brazil). All chemicals used in the experiments were of analytical grade and of the highest purity.

2.2. Animals. Male and female Wistar rats of 200-300 g bodyweight were used for all experiments, which were performed in accordance with the guidelines of Committee on Care and Use of Experimental Animal Resources (UFSM, Brazil) and in accordance with international guidelines.

2.3. Sepsis Induction and Samples Preparation. Animals were randomly divided into two groups (5 rats in each group): control and induced sepsis. To induce sepsis, it was used a model of cecal ligation and puncture as previously described [12]. After $12 \mathrm{~h}$ of induction, animals were anesthetized with isoflurane and the whole blood was collected through cardiac puncture in tubes containing ethylenediamine tetraacetic acid.

2.4. Isolation of Mononuclear Cells from Blood. Lymphocyterich mononuclear cells were isolated from blood collected with ethylenediamine tetraacetic acid and separated on Ficoll-Histopaque density [13] as previously described. The percentage of lymphocytes was superior to $93 \%$ as previously described [14].

2.5. NTPDase Activity Assay. After the isolation of lymphocytes, the NTPDase activity was determined as described previously by our group [15], measuring the amount of liberated inorganic phosphate $(\mathrm{Pi})$ using a colorimetric assay. The reaction medium contained $0.5 \mathrm{mM} \mathrm{CaCl}_{2}, 120 \mathrm{mM} \mathrm{NaCl}$, $5 \mathrm{mM} \mathrm{KCl}, 60 \mathrm{mM}$ glucose, and $50 \mathrm{mM}$ Tris-HCl buffer ( $\mathrm{pH}$ 8.0) in a final volume of $200 \mu \mathrm{L}$. Then $20 \mu \mathrm{L}$ of intact mononuclear cells suspended in saline solution was added to the reaction medium $(2-4 \mu \mathrm{L}$ protein) and preincubated for $10 \mathrm{~min}$ at $37^{\circ} \mathrm{C}$. The reaction was started by adding the substrate (ATP or ADP) at a final concentration of $2 \mathrm{mM}$ and was stopped with $200 \mu \mathrm{L}$ of $10 \%$ trichloroacetic acid to provide a final concentration of $5 \%$. The samples were chilled on ice for $10 \mathrm{~min}$ before assaying the release of $\mathrm{Pi}$ as described previously [16], using malachite green as a colorimetric reagent and $\mathrm{KH}_{2} \mathrm{PO}_{4}$ as a standard. Light absorbance was measured at $630 \mathrm{~nm}$ in a spectrophotometer (Biospectro SP22). Control reactions were performed by adding the enzyme preparation after the addition of trichloroacetic acid to correct for nonenzymatic nucleotide hydrolysis. All samples were run in triplicate, and the specific activity is reported as nanomoles of Pi released per minute per milligram of protein.

2.6. Protein Determination. Protein was measured by the Coomassie blue method as described previously [17]. Briefly, a solution of Coomassie $(117 \mu \mathrm{L}$ Coomassie, $0.85 \mathrm{M}$ ethyl alcohol, and $1.46 \mathrm{M}$ ortho-phosphoric acid) was prepared. A standard curve with bovine serum albumin varying from 0.1 to $0.5 \mathrm{mg}$ of protein per milliliter was performed. To quantify the protein content, $50 \mu \mathrm{L}$ of sample was added to $2.5 \mathrm{~mL}$ of Coomassie solution and, after $5 \mathrm{~min}$, the absorbance was read in a spectrophotometer (Biospectro SP-22) at $595 \mathrm{~nm}$.

2.7. Anatomopathologic Analysis. Samples of liver, kidney, and lung tissue, ex vivo, were collected and fixed in $10 \%$ formalin solution and then dehydrated and embedded in paraffin, followed by sectioning and histological staining with hematoxylin and eosin (H\&E). The slides were observed in an optical microscope $(400 \mathrm{x})$ to check for possible changes in the respective tissues.

2.8. Statistical Analysis. Statistical analysis was performed using the nonparametric Mann-Whitney test, since results did not show Gaussian distributions. $P<0.05$ was considered to represent a significant difference among the analyses performed. All data were expressed as mean \pm standard error of the mean.

\section{Results}

3.1. Clinical Features. After $12 \mathrm{~h}$ of sepsis induction, the animals showed swollen abdominal region with fecal material release, as described by Benjamin [18].

3.2. NTPDase Activity in Lymphocytes. The statistical analysis demonstrated that animals from septic group had an increased ATP hydrolysis $(P<0.01)$ (Figure $1(\mathrm{a}))$ but did not show any statistical difference $(P>0.05)$ in regard to ADP hydrolysis (Figure 1(b)).

3.3. Anatomopathologic Analysis. Kidney section of control group showed normal (A) glomeruli and convoluted tubules within renal cortex. No abnormal proliferations were seen. The medulla and hilum were microscopically normal. Atypical congested convoluted tubules were seen in kidneys of rats with induced sepsis. In some areas, the convoluted tubules were lined by crowded hyperchromatic cuboidal cells, which had decreased cytoplasm. Kidney sections also showed some congested glomeruli, besides tubular necrosis with multiple points along the nephron with cellular vacuolization (degeneration) and necrosis. Shedding or desquamation of cell 


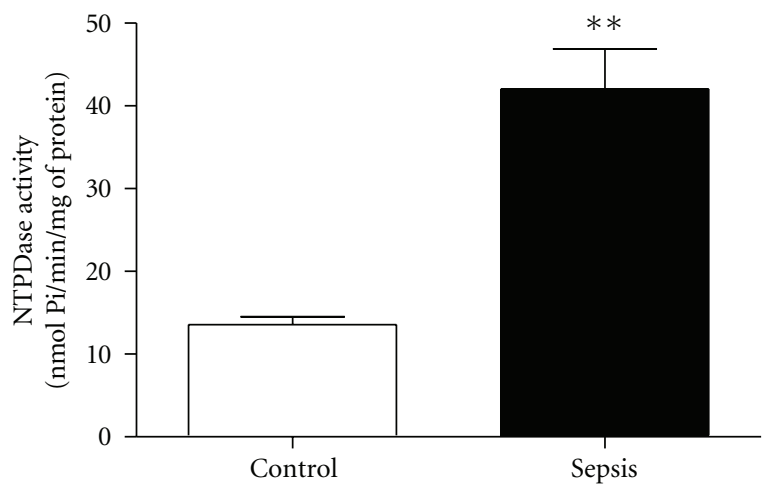

(a)

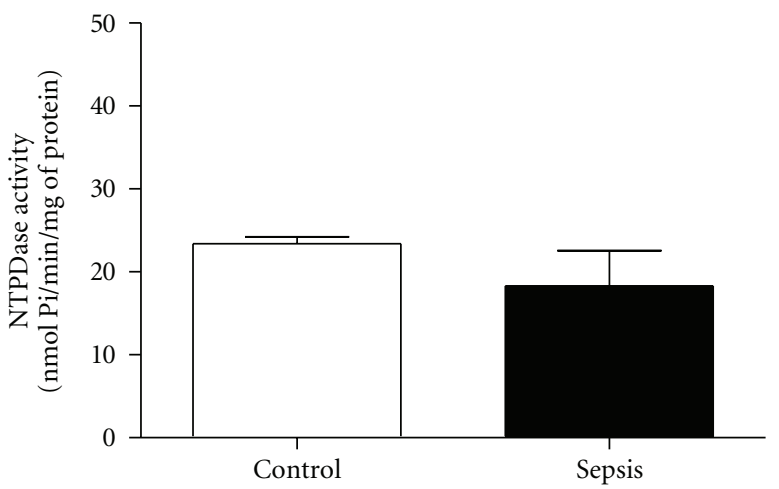

(b)

Figure 1: NTPDase activity in peripheral blood lymphocytes from rats with induced sepsis using (a) ATP or (b) ADP as a substrate. Bars represent means \pm standard error of the mean $(P<0.01, n=5)$. Mann-Whitney test. ${ }^{* *}$ Indicates a significant difference compared with control.

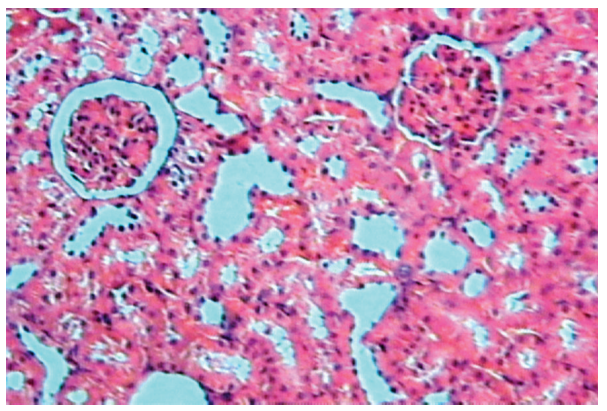

(a)

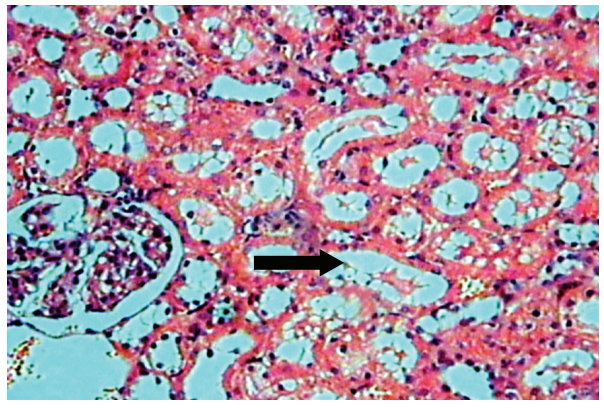

(c)

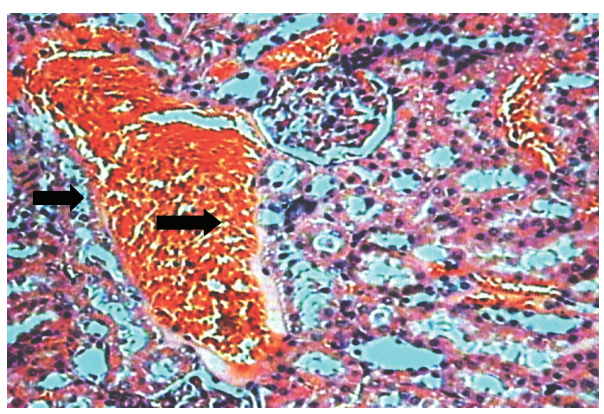

(e)

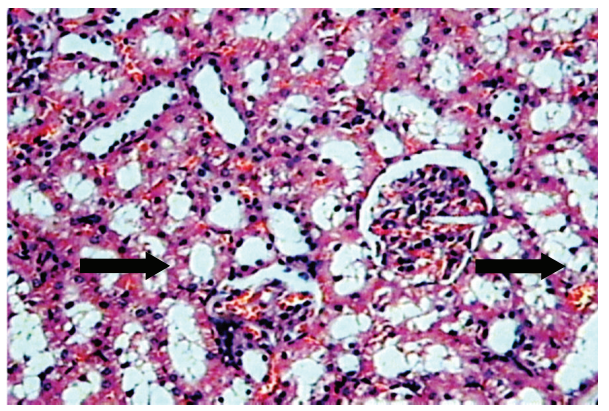

(b)

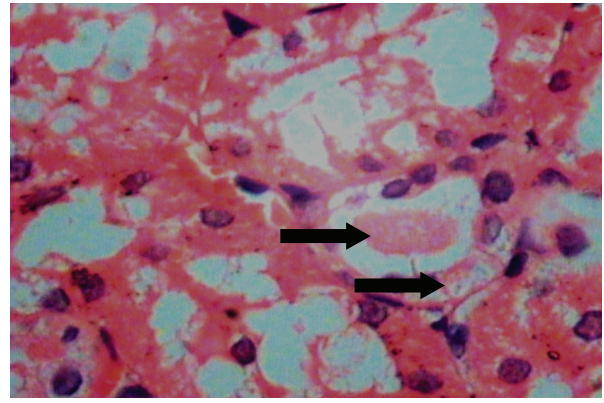

(d)

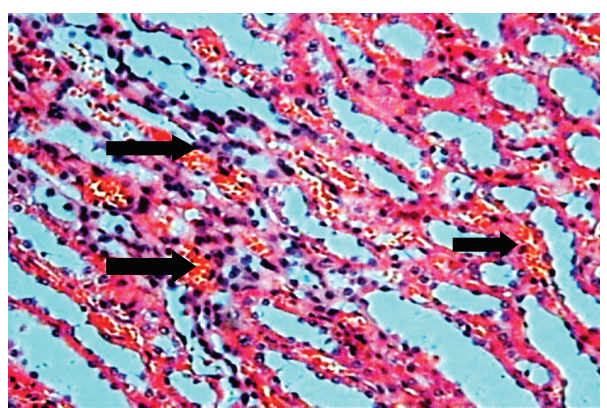

(f)

Figure 2: (a) Normal architecture of kidney with normal convoluted tubules and glomeruli (HE, 10x). (b) Abnormal kidney of rat with induced sepsis showed architecture with cellular vacuolization (degeneration) (HE, 10x). (c) Congested tubules (HE, 10x). (d) Congested convoluted proximal tubules lined by vacuolar cells with absence of individual tubular cells (HE, 40x). (e) Presence of substantial vascular congestion in capllaries in the cortex and desquamation of cell fragments into lumen (HE, 10x). (f) The medullar area shows congested peritubular capillaries (vasa recta) with discrete polymorphonuclear infiltrate (HE, 10x). 


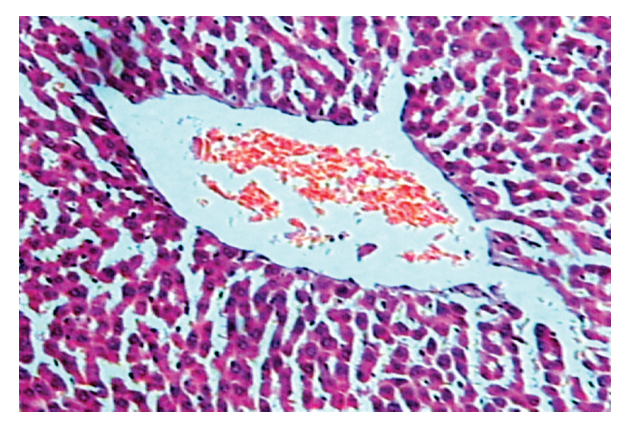

(a)

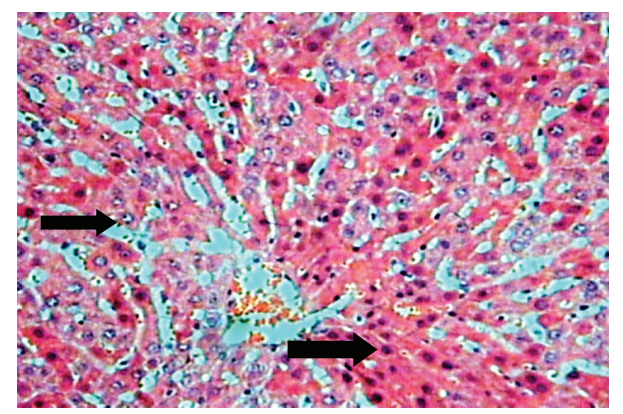

(b)

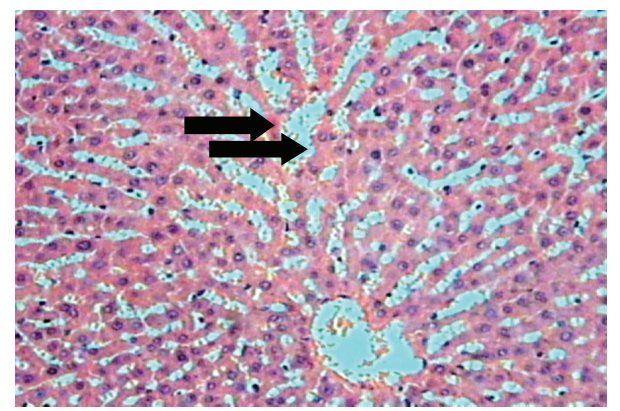

(c)

FIgURE 3: (a) Liver sections of control rats showing normal histological appearance (HE, 10x). (b) Liver of the rats with induced sepsis showed a partial hepatic cord disarrangement and an increased number of hepatocytes in process of involution with pyknotic nuclei and condensed cytoplasm (HE, 10x). (c) The central vascular sinusoids are dilated and congested filled with erythrocytes. Periportal hepatocytes are normal (not showed) (HE, $10 \mathrm{x})$.

fragments into lumen and absence of individual tubular cells were also viewed. Presence of marked vascular congestion in arterioles and peritubular capillaries in the renal cortex and medullar area were observed (Figure 2). These findings suggest tubular necrosis.

The liver section of control group showed normal histological appearance with normal polyhedral hepatocytes. The rats with induced sepsis showed important morphologic changes, as vascular congestion and some marks of necrosis. The microscopic analysis showed partial hepatic cord disarrangement and increased number of hepatocytes undergoing involution with pyknotic nuclei and condensed cytoplasm. The central veins, spaces of Disse, and central vascular sinusoids were dilated and congested, filled with erythrocytes (Figure 3).

The lung section of control group showed normal histological appearance showing a bronchiole and adjacent alveoli, airways, blood vessel, and parenchyma with delicate alveolar septal tissues. The rats with induced sepsis different degrees of lung consolidation developed and alveolar spaces were infiltrated with a large number of mononuclear cells (Figure 4).

\section{Discussion}

The extracellular nucleotides are important signaling molecules, being essential to start and maintain the inflammatory reactions [19]. These nucleotides are found in high concentrations within cells when compared to the extracellular environment, which is a characteristic of signaling molecules. Thus, in response to different stimulus or conditions, including damage to plasmatic membrane induced by hypoxia, ischemia, or inflammation, increasing concentrations of nucleotides can be released to the extracellular environment [20]. During the inflammatory process, ATP is involved in the development of inflammation by several processes: released histamine from mastocytes, production of prostaglandins, and production and release of cytokines from immune cells [21]. Besides these release forms, related mainly to cellular injury, ATP may be released from intact cells by physiological mechanisms, as it occurs, for example, in nervous transmission.

In this study, histological analysis showed several morphological changes in organs analyzed from septic group in tissues such as kidney, liver, and lung. Among the more outstanding changes include the marked vascular congestion, necrosis, and infiltration of mononuclear cells in agreement with previous studies [22] in lung tissue.

Furthermore, the results also demonstrated that the animals induced to sepsis had an increase in the NTPDase activity (ATP as a substrate) and no alterations in the ADP hydrolysis. The increased NTPDase activity in lymphocytes and the morphological alterations observed in the septic group are probably related with a physiological increase of ATP in the extracellular milieu. A physiological role for ATP is the regulation of inflammation [23], and it is known that once released, it interacts with specific receptors, denominated purinergic receptors, which establish a communication between cells [24]. The action of ATP during the inflammatory process occurs primarily via activation of purinergic P2X receptors, which may lead the cellular apoptosis [25]. Extracellular ATP has been shown to induce shedding of L-selectin from $\mathrm{T}$ lymphocytes via activation of purinergic P2X7 receptors [26-30]. Since L-selectin is primarily involved in lymphocyte homing to lymphoid tissues and is shed upon lymphocyte activation, ATP was proposed to be involved in migration of activated lymphocytes to sites of inflammation [31]. Additionally, there was verified [32] a possible involvement of $\mathrm{P} 2 \mathrm{X} 7$ receptors in the lymphocytes proliferation and the activation of interleukin- 2 transcription factor as a consequence. Interleukin-2 is a proinflammatory cytokine as interleukin-6, tumor necrosis factor- $\alpha$, 


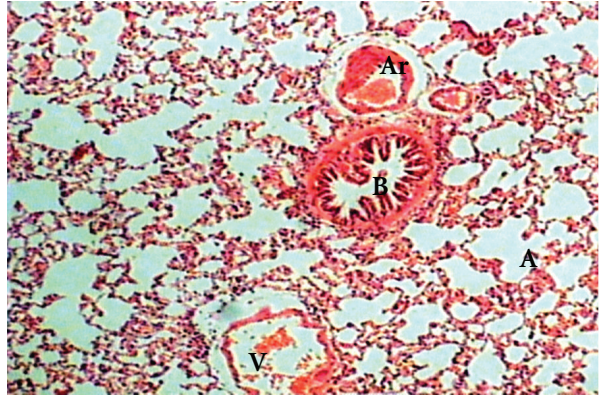

(a)

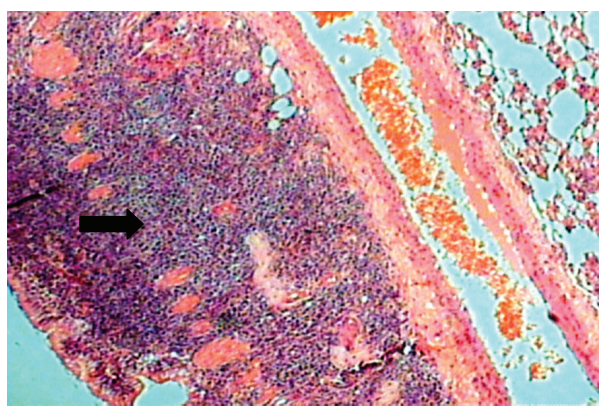

(c)

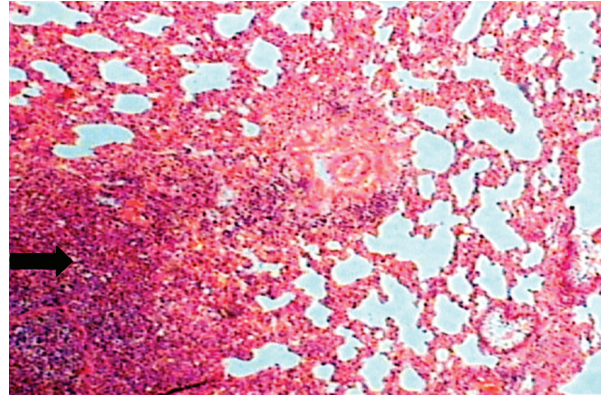

(b)

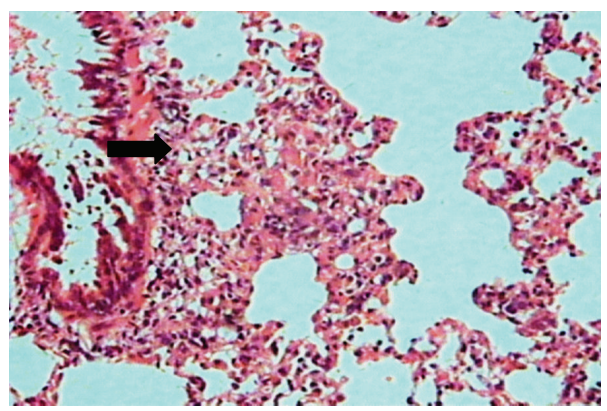

(d)

FIGURE 4: (a) Lung section of control group with normal histological appearance of alveolus (A), bronchiole (B), arteriole (Ar) and venule $(V)$ (HE, 10X). (b) Lung of rats with induced sepsis showing different degrees of lung consolidation and alveolar spaces were infiltrated with a large number of mononuclear cells (HE, 10x). (c) Presence of mononuclear infiltrated in the wall of bronchiole (HE, 10x). (d) Local thickening of infiltrated mononuclear cells in alveolar wall and peribronchial area (HE, 20x).

and interferon- $\gamma[1]$, which participate in the inflammatory response regulation in sepsis [33]. These results corroborate with our findings, which suggest an increased extracellular ATP level in the animals induced to sepsis.

It is proposed that the systemic injuries promoted by this induced clinical condition may have increased the extracellular levels of ATP as a consequence of the cellular damage observed. In this context, the increased ATPasic activity was probably induced as a dynamic response to clean up the elevated ATP levels resulting from cellular death.

\section{Conflict of Interests}

There is no actual or potential conflict of interest.

\section{Acknowledgments}

This work was supported by Conselho Nacional de Desenvolvimento Científico e Tecnológico (CNPq), Fundação de Amparo à Pesquisa do Rio Grande do Sul (FAPERGS), and Fundação Coordenação de Aperfeiçoamento de Pessoal de Nível Superior (CAPES), Brazil.

\section{References}

[1] R. C. Bone, C. J. Grodzin, and R. A. Balk, "Sepsis: a new hypothesis for pathogenesis of the disease process," Chest, vol. 112, no. 1, pp. 235-243, 1997.
[2] D. M. Vandijck, J. M. Decruyenaere, and S. I. Blot, "The value of sepsis definitions in daily ICU-practice," Acta Clinica Belgica, vol. 61, no. 5, pp. 220-226, 2006.

[3] M. Holub and C. F. Benjamin, "Atualização sobre mediadores e modelos experimentais de sepse," Medicina, vol. 34, pp. 1826, 2001.

[4] M. S. Rangel-Frausto, "Sepsis: still going strong," Archives of Medical Research, vol. 36, no. 6, pp. 672-681, 2005.

[5] E. D. Crouser, "Mitochondrial dysfunction in septic shock and multiple organ dysfunction syndrome," Mitochondrion, vol. 4, no. 5-6, pp. 729-741, 2004.

[6] C. A. Mastronardi, V. Srivastava, W. H. Yu, W. L. Dees, and S. M. McCann, "Lipopolysaccharide-induced leptin synthesis and release are differentially controlled by alpha-melanocytestimulating hormone," NeuroImmunoModulation, vol. 12, no. 3, pp. 182-188, 2005.

[7] S. C. Robson, J. Sévigny, and H. Zimmermann, "The E-NTP Dase family of ectonucleotidases: structure function relationships and pathophysiological significance," Purinergic Signalling, vol. 2, no. 2, pp. 409-430, 2006.

[8] R. B. Gayle III, C. R. Maliszewski, S. D. Gimpel et al., "Inhibition of platelet function by recombinant soluble Ecto-ADPase/CD39," Journal of Clinical Investigation, vol. 101, no. 9, pp. 1851-1859, 1998.

[9] M. R. C. Schetinger, V. L. P. Vieira, V. M. Morsch, and D. Balz, "ATP and ADP hydrolysis in fish, chicken and rat synaptosomes," Comparative Biochemistry and Physiology B, vol. 128, no. 4, pp. 731-741, 2001.

[10] F. Di Virgilio, P. Chiozzi, D. Ferrari et al., "Nucleotide receptors: an emerging family of regulatory molecules in blood cells," Blood, vol. 97, no. 3, pp. 587-600, 2001. 
[11] A. Surprenant, F. Rassendren, E. Kawashima, R. A. North, and G. Buell, "The cytolytic P2Z receptor for extracellular ATP identified as a P2X receptor (P2X7)," Science, vol. 272, no. 5262, pp. 735-738, 1996.

[12] D. Rittirsch, M. S. Huber-Lang, M. A. Flierl, and P. A. Ward, "Immunodesign of experimental sepsis by cecal ligation and puncture," Nature Protocols, vol. 4, no. 1, pp. 31-36, 2009.

[13] A. Böyum, "Isolation of mononuclear cells and granulocytes from human blood. Isolation of monuclear cells by one centrifugation, and of granulocytes by combining centrifugation and sedimentation at $1 \mathrm{~g}$," Scandinavian Journal of Clinical and Laboratory Investigation, vol. 97, supplement, pp. 77-89, 1968.

[14] J. A. D. S. Jaques, J. F. Peres Rezer, J. B. Ruchel et al., "A method for isolation of rat lymphocyte-rich mononuclear cells from lung tissue useful for determination of nucleoside triphosphate diphosphohydrolase activity," Analytical Biochemistry, vol. 410, no. 1, pp. 34-39, 2011.

[15] D. B. R. Leal, C. A. Streher, T. N. Neu et al., "Character- ization of NTPDase (NTPDase1; Ecto-apyrase; ecto-diphosphohydrolase; CD39; EC 3.6.1.5) activity in human lymphocytes," Biochimica et Biophysica Acta, vol. 1721, no. 1-3, pp. 9-15, 2005.

[16] K. M. Chan, D. Delfert, and K. D. Junger, "A direct colorimetric assay for Ca2+-stimulated ATPase activity," Analytical Biochemistry, vol. 157, no. 2, pp. 375-380, 1986.

[17] M. M. Bradford, "A rapid and sensitive method for the quantitation of microgram quantities of protein utilizing the principle of protein dye binding," Analytical Biochemistry, vol. 72, no. 1-2, pp. 248-254, 1976.

[18] C. F. Benjamin, "Present understanding of mediators and experimental models of sepsis," Medicina, vol. 34, pp. 18-26, 2001.

[19] D. T. Luttikhuizen, M. C. Harmsen, L. F. M. H. De Leij, and M. J. A. Van Luyn, "Expression of P2 receptors at sites of chronic inflammation," Cell and Tissue Research, vol. 317, no. 3, pp. 289-298, 2004.

[20] H. Zimmermann, "Nucleotides and cd39: principal modulatory players in hemostasis and thrombosis," Nature Medicine, vol. 5, no. 9, pp. 987-988, 1999.

[21] F. D. Virgilio, "Purinergic P2X7 receptor: a pivotal role in inflammation and immunomodulation," Drug Development Research, vol. 45, no. 3-4, pp. 207-213, 1998.

[22] A. D’Acampora, J. Bernhardt, J. Serafim, D. Farias, and R. Tramonte, "Efeitod da castração pós-natal sobre o tecido pulmonar após sepse experimental de origem abdominal em ratos," Acta Cirúrgica Brasileira, vol. 19, pp. 115-119, 2004.

[23] J. A. D. S. Jaques, J. F. P. Rezer, J. B. Ruchel et al., "Lung and blood lymphocytes NTPDase and acetylcholinesterase activity in cigarette smoke-exposed rats treated with curcumin," Biomedicine and Preventive Nutrition, vol. 1, no. 2, pp. 109$115,2011$.

[24] G. Burnstock, "Introduction: P2 receptors," Current Topics in Medicinal Chemistry, vol. 4, no. 8, pp. 793-803, 2004.

[25] E. Bulanova, V. Budagian, Z. Orinska et al., "Extracellular ATP induces cytokine expression and apoptosis through P2X7 receptor in murine mast cells," Journal of Immunology, vol. 174, no. 7, pp. 3880-3890, 2005.

[26] J. I. Elliott and C. F. Higgins, "Major histocompatibility complex class I shedding and programmed cell death stimulated through the proinflammatory $\mathrm{P} 2 \mathrm{X} 7$ receptor: a candidate susceptibility gene for NOD diabetes," Diabetes, vol. 53, no. 8, pp. 2012-2017, 2004.
[27] B. J. Gu, W. Y. Zhang, L. J. Bendall, I. P. Chessell, G. N. Buell, and J. S. Wiley, "Expression of P2X7 purinoceptors on human lymphocytes and monocytes: evidence for nonfunctional P2X7 receptors," American Journal of Physiology, vol. 279, no. 4, pp. C1189-C1197, 2000.

[28] G. P. Jamieson, M. B. Snook, P. J. Thurlow, and J. S. Wiley, "Extracellular ATP causes loss of L-selectin from human lymphocytes via occupancy of P2Z purinoceptors," Journal of Cellular Physiology, vol. 166, no. 3, pp. 637-642, 1996.

[29] J. M. Labasi, N. Petrushova, C. Donovan et al., "Absence of the P2X7 receptor alters leukocyte function and attenuates an inflammatory response," Journal of Immunology, vol. 168, no. 12, pp. 6436-6445, 2002.

[30] M. Seman, S. Adriouch, F. Scheuplein et al., "NAD-induced T cell death: ADP-ribosylation of cell surface proteins by ART2 activates the cytolytic P2X7 purinoceptor," Immunity, vol. 19, no. 4, pp. 571-582, 2003.

[31] M. J. L. Bours, E. L. R. Swennen, F. Di Virgilio, B. N. Cronstein, and P. C. Dagnelie, "Adenosine 5'-triphosphate and adenosine as endogenous signaling molecules in immunity and inflammation," Pharmacology and Therapeutics, vol. 112, no. 2, pp. 358-404, 2006.

[32] V. Budagian, E. Bulanova, L. Brovko et al., "Signaling through $\mathrm{P} 2 \mathrm{X} 7$ receptor in human $\mathrm{T}$ cells involves p56lck MAP kinases, and transcription factors AP-1 and NF- $\kappa$ B," Journal of Biological Chemistry, vol. 278, no. 3, pp. 1549-1560, 2003.

[33] A. Hillenbrand, U. Knippschild, M. Weiss et al., "Sepsis induced changes of adipokines and cytokines - septic patients compared to morbidly obese patients," BMC Surgery, vol. 10, article no. 26, 2010. 

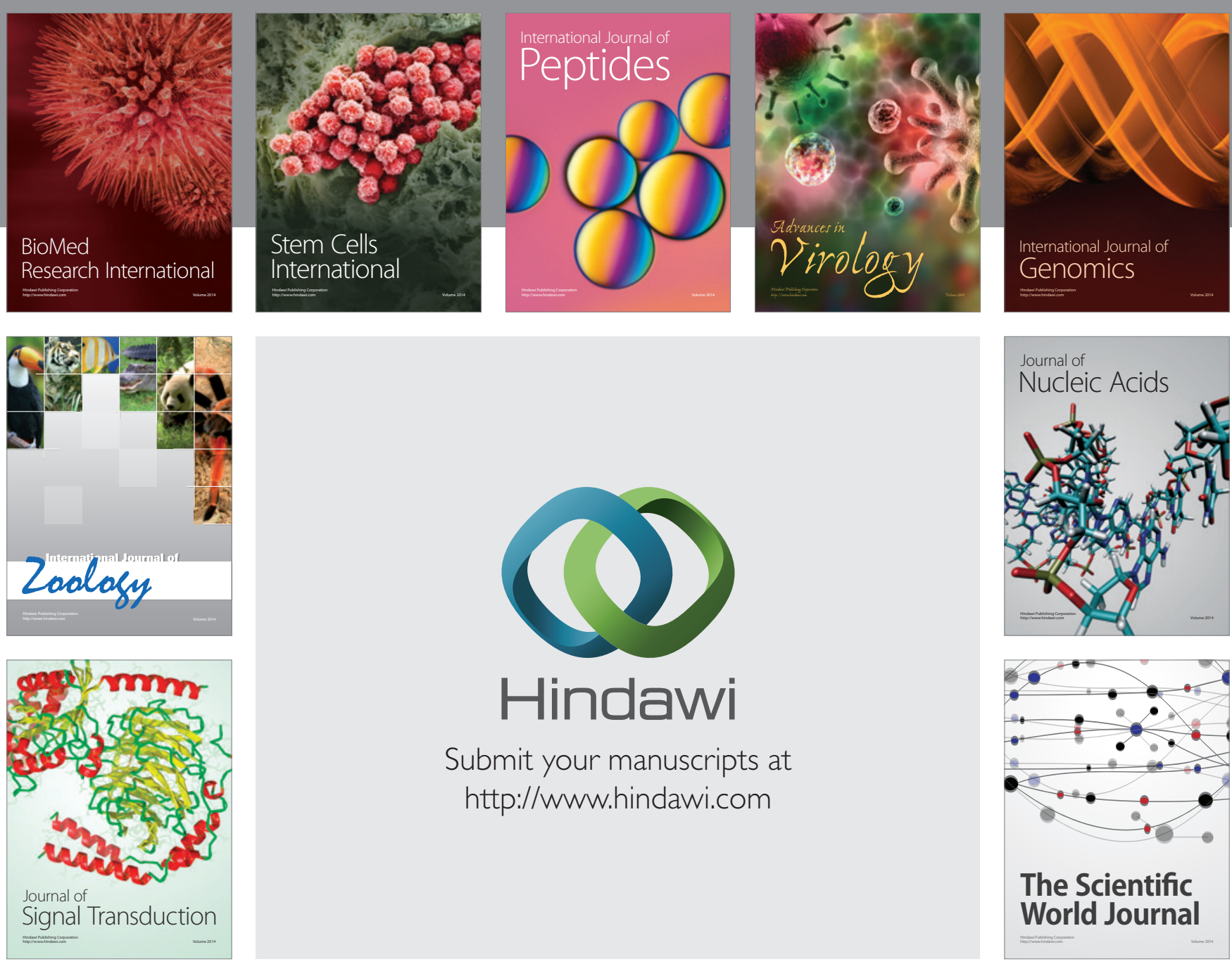

Submit your manuscripts at

http://www.hindawi.com
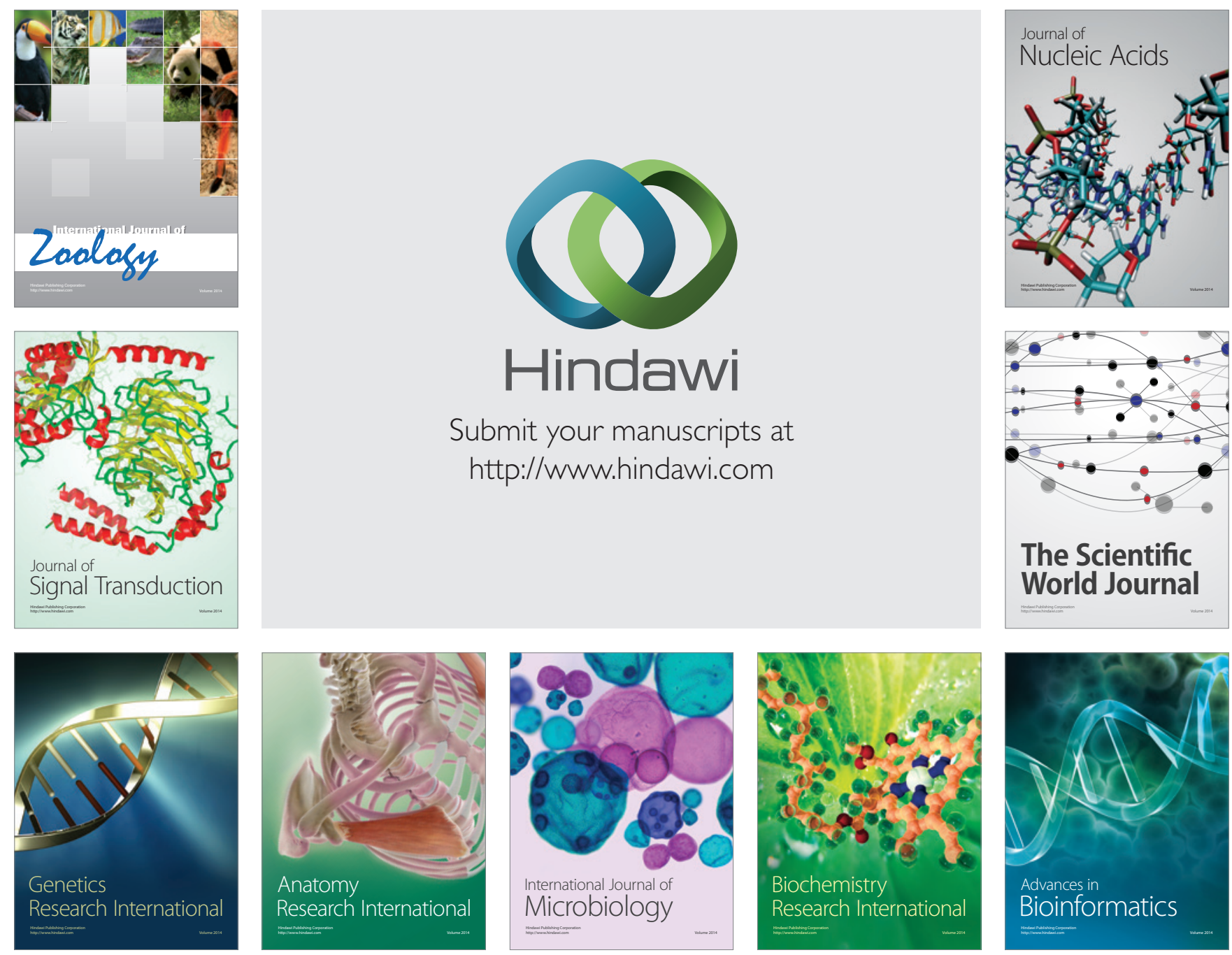

The Scientific World Journal
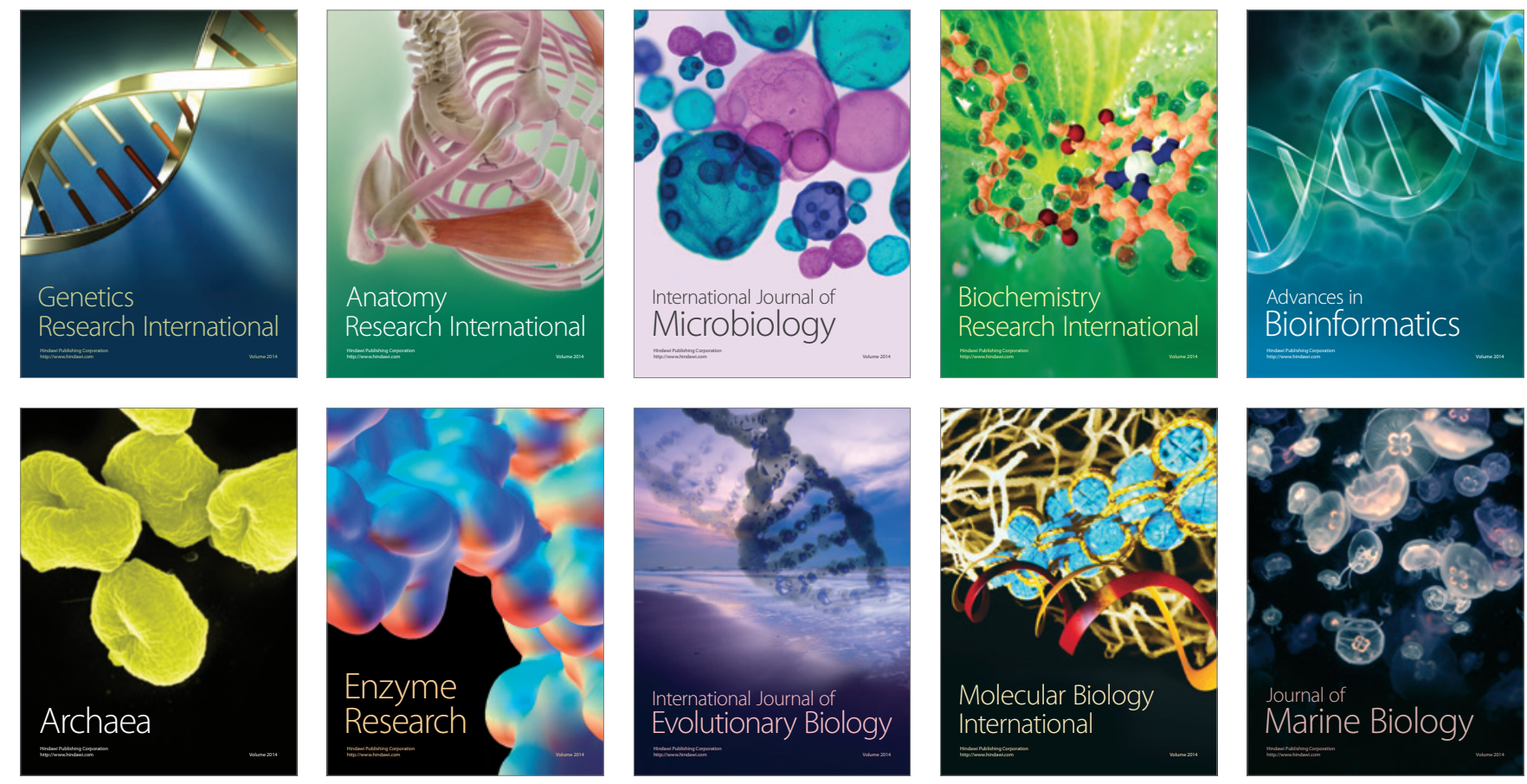